\title{
Moving a company's COMI to achieve a restructuring: factors for consideration
}

\author{
by Anna Kaczor
}

\section{INTRODUCTION}

This article sets out the main factors for establishing a company's centre of main interests ("COMI") and considers what should be done in order to successfully move the COMI to another jurisdiction.

It is clear that European companies are still struggling with the consequences of global recession. Companies in financial distress may need to be restructured and consider the advantages of forum shopping. In simple terms, forum shopping involves identifying an optimal jurisdiction for a restructuring or insolvency, and a transfer of assets and/or judicial proceedings to this jurisdiction. So, for example, in order to take advantage of the availability of an alternative insolvency law regime, companies may move their COMI to the desired jurisdiction.

\section{ESTABLISHING THE COMI OF A COMPANY}

Under Council Regulation (EC) No 1346/2000 of May 29, 2000 on Insolvency Proceedings ("EU Insolvency Regulation") which came into effect on May 31, 2002, a company may only be put into main insolvency proceedings in the EU Member State where its COMI is located. The EU Insolvency Regulation is a European law measure binding fully EU Member States (apart from Denmark, which opted out). Once main insolvency proceedings have been opened they are automatically recognised in other EU Member States. Any disagreement between Member States as to where the COMI is located should ultimately be resolved by the European Court of Justice (ECJ).

The Insolvency Regulation does not provide a definition of the COMI. Nevertheless, there is a rebuttable presumption contained in Article 3(1) of the EU Insolvency Regulation that the COMI of a company is the place of its registered office. In the well-known case of Eurofood IFSC C-341/04 of May 2, 2006, the ECJ made it clear that the registered office presumption may be rebutted only if factors which are both objective and ascertainable by third parties enable it to be established that an actual situation exists which is different from that which locating it at its registered office is deemed to reflect. The ECJ approach shows that it is not easy to rebut the registered office presumption.

\section{REBUTTING THE REGISTERED OFFICE PRESUMPTION}

It is not necessary to shift the registered office itself to rebut the presumption that the COMI is the place of the registered office. The courts will consider a number of factors to ascertain the location of the COMI. In the Eurofood IFSC judgment, the ECJ considered whether the debtor was merely a letterbox company with its address in one EU Member State for the purposes of convenience and its actual business in another country. In the matter of $D B P$ Holdings Limited [2004] EWHC 1941 the English High Court considered whether the company made any public statements about its location, eg to its creditors or to the authorities. Apart from the office location it is necessary to take into account the most important third parties, namely creditors. In Shierson v Vlieland-Boddy [2005] EWCA Civ 974 the Court of Appeal took into consideration the most likely creditors, including potential creditors, and where they viewed the most important debtor's head office functions to be carried out. Other factors regarding creditors include the law governing the creditors' contracts with the debtor, and the location of the creditors (Re Sendo Ltd [2005] EWHC 1604 (Ch)).

There are many other factors for establishing a company's COMI that the court may take into consideration, and not all can be listed here. It is worth mentioning, however, the following factors concerning: key decisions, the board of directors, financing, employees, and the group head office function. As far as the key decisions are concerned, it has been held in Re Sendo Ltd that the person making key strategic, operational and financial decisions, where this person is based, and where approvals for large transactions come from, are factors for establishing COMI. It has been decided in the same case that the venue of the board meetings and the place where directors live and where they are based should be also regarded as factors for establishing COMI. Moving on to the financing factors, in the matter of 
DBP Holdings Limited the English High Court gave consideration to: the place of negotiations aimed at arranging the financing, the location of the banks and the company's bank accounts, and the place where banks contacted the debtor. Another factor for establishing a company's COMI relates to employees. In Re 3t Telecom Ltd [2005] EWHC 275 (Ch) the court took into account the place where employees were based. And finally, the courts may consider the location of the group head office function (Re Collins and Aikman Corporation Group [2005] EWHC 1754 (Ch)).

Of those aforementioned factors, there is little guidance in the EU Insolvency Regulation to indicate which should be given more importance - it has been left to national courts to decide on the relative importance of each on a case-bycase basis. Recital 13 to the preamble of the EU Insolvency Regulation states that the COMI should correspond to the location where the debtor conducts the administration of his interests on a regular basis. Before the Eurofood IFSC judgment there was a difference between the continental European approach and that used in England and Wales. The continental approach focused on the "centre of operations". This refers to the location where the COMI is most easily ascertainable by third parties, and therefore creditors are an important consideration. The "mind management approach" in England and Wales focused on the location where important decisions are made.

Following the Eurofood IFSC judgment, the third parties' perception as to where a company conducts its administration is given significant weight by courts across the EU. So, while the "mind management approach" is more practical, special consideration must now be paid to creditors and their perception of where the company conducts business. In general, one single factor is not enough to rebut the registered office presumption, and the courts take into account a number of factors, especially the location where important decisions are made, creditors, and the board of directors.

\section{COMI SHIFT}

Despite the fact that one of the purposes of the EU Insolvency Regulation was to avoid forum-shopping, there is still scope for COMI migration. There are some good reasons for the migration of a company's COMI to certain jurisdictions. For example, stakeholders may prefer a more familiar restructuring environment. Other reasons may include: timing of the restructuring; the degree of control over the restructuring process; the appointment of the office holders, ie administrators, liquidators and trustees; the availability of pre-packs; the possibility to cram down creditors; and the scope of directors' duties. A significant portion of cross-border traffic has moved towards English jurisdiction in order to benefit from English pre-packs, schemes of arrangement and company voluntary arrangements. Examples of corporate migrants in the UK include Deutsche Nickel AG, Damovo, Schefenacker, and most recently Hellas Telecommunications (Luxembourg) II SCA.
COMI migration - including the transfer of a company's registered office - is governed by national law rather than EU law. Interestingly, in its December 2008 decision in Cartesio C-210/06 the ECJ ended speculation that national legislation which may restrict the ability of a company to move its COMI is incompatible with the law of the European Union. Cartesio wished to transfer its operational headquarters from Hungary to Italy while remaining registered in Hungary. The referring court sought the ECJ's guidance on whether applicable Hungarian legislation, which prevented Cartesio from continuing to be governed by Hungarian law, was compatible with the right of establishment. It is submitted that the Cartesio case is not a step forward in favour of companies trying to transfer their COMI to other jurisdictions, as Member States can effectively restrict COMI migration by national legislation.

\section{TECHNIQUES OF MIGRATION}

The simplest way to move a company's COMI to another EU Member State is to move the company's registered office. As mentioned above, the transfer of a company's registered office is governed by local law. There is also a type of company called Societas Europaea formed under the European Company Statute which can transfer its registered office with ease simply by reregistering in another Member State. The grass is, however, not always greener under Societas Europaea since the ease with which it can move its registered office between EU Member States may actually weaken the registered office presumption.

Migration is used to move a company from one EU Member State to another. Although there are numerous techniques of migration, it is submitted that moving a German company to England is particularly interesting. A good example of the successful use of migration involving the German law of succession concerns Deutsche Nickel Aktiengesellschaft (a German limited joint stock company). The story began with the sale of Deutsche Nickel's shares to DNICK Ltd, a newly founded private company limited by shares incorporated under English law. Following the sale, Deutsche Nickel Aktiengesellschaft was converted into a Kommanditgesellschaft (a limited partnership under German law). After the transformation, DNICK Ltd became a general partner and EuroCoin Ltd incorporated under English law and became a limited partner. Then, the limited partner retired. Subsequently, the general partner became the sole partner. According to German law, without any limited partners the partnership ceases to exist as a separate legal entity. Under German laws of succession, the general partner automatically becomes the full legal successor to the assets and liabilities of a limited partnership. So effectively German Deutsche Nickel AG has been transformed into an English registered DNICK Ltd. This illustrates how a German corporate migrant managed to take advantage of English restructuring laws.

COMI migration can also be achieved without reliance on the law of a certain EU Member State. For instance, in the 
restructuring of the IT company Damovo, its COMI was shifted from Luxemburg to London by moving its head office functions to England, notifying all of the suppliers, creditors and counterparties of the move, setting up bank accounts in England, and holding board meetings in England. This was enough to demonstrate that Damovo's COMI had moved to England. The migration enabled the company to effect a prepackaged administration under English law. Somewhat similar is the case of Hellas Telecommunications (Luxembourg) II SCA [2009] EWHC 3199 (Ch) where the English court decided that the COMI of Hellas Telecommunications (Luxembourg) II SCA ("Hellas II") had been effectively transferred from Luxemburg to England to take advantage of more beneficial restructuring laws (probably the largest pre-pack administration in history). The COMI moved to England despite the fact that the company's registered office remained in Luxembourg. In order to decide where the COMI was located the judge took into consideration the following facts: a new head office was opened in London; Hellas II notified its creditors that it had relocated to England and there was a press release to that effect; it had an active bank account in London; Hellas II was registered at Companies House as a foreign company and as a UK establishment of an overseas company; all negotiations between Hellas II and its creditors were conducted in London; and the company's senior creditors were prepared to approve a pre-pack sale following an English administration order.

\section{DANGERS OF SHIFTING A COMPANY'S COMI}

The danger associated with moving the COMI to another jurisdiction is that creditors may be unhappy with the proposed change. When creditors become aware of the company's preparation for the shift, they could file for insolvency in a jurisdiction which is not optimal for the company. Recital 13 of the EU Insolvency Regulation states that: "The centre of main interests should correspond to the place where the debtor conducts the administration of his interests on a regular basis and is therefore ascertainable by third parties." Therefore creditors and other third parties need to be notified about the relocation. If creditors file for insolvency before the COMI shift, this would have far-reaching consequences for prospective corporate migrants, especially in view of the ECJ decision in Susanne Staubitz-Schreiber (C-01/04, January 17,2006 ) that a filing alone may suffice to prevent a COMI shift. The ECJ decided that the time of determining the debtor's COMI is the time of filing the petition requesting the court to open insolvency proceedings. Therefore, any attempts to move the COMI after the date of filing would be disregarded in the process of determining the location of the company's COMI.

Even if creditors do not cause trouble, there is a danger in moving a company's registered office and leaving the COMI behind. This unfortunate situation took place in the case of Hans Brochier Holdings Ltd v Exner [2007] BCC 127. A German construction company moved its registered office to England to take advantage of English insolvency law. The directors appointed English administrators on an out-of-court basis Then, German employees applied to a German court, which decided that the company's COMI was in Germany. The German court, unaware of the appointment of English administrators, appointed Mr Exner as a preliminary insolvency practitioner. Subsequently, the English administrators became aware of the decision of the German court and concluded shortly after their appointment that the company's COMI remained in fact in Germany and so applied to an English court for directions. The English administrators sought a declaration that the English administration proceedings were not the main proceedings, but territorial proceedings.

The English court held that the company's COMI was in Germany and that the appointment of the English administrators was invalid. Subsequently, the directors appointed English administrators for a second time on the basis that Hans Brochier had an establishment in the UK. The directors' attempt simply failed because Mr Exner successfully applied to the English court for a finding that the second out-of-court appointment was invalid, arguing that Hans Brochier did not have an establishment in the UK. The outcome of this case is particularly interesting because the English court decided for the first time that a company with its registered office in England had neither its COMI nor its establishment in England. In contrast to the success of the migration of Deutsche Nickel AG from Germany to England, the case of Hans Brochier is a good example of a migration disaster and shows what happens if the directors do not make sure that the COMI has in fact been shifted.

\section{CONCLUSION}

Cross-border forum shopping for an optimal jurisdiction has recently become popular in the European Union. Of course any distressed company might like to make hay while the sun shines, and move its COMI in order to benefit from the availability of a different insolvency law regime as happened in the example of Deutsche Nickel AG. It seems, however, that moving the COMI requires strong strategic planning. There is no universal recipe for reincarnating a distressed company in another EU Member State, especially in a short period of time. There is always a risk of leaving the COMI behind, as happened in the Hans Brochier case. Given the emphasis on the place where third parties perceive the company to conduct its administration, it is, therefore important to notify third parties of the location from which headquarter functions are carried out. Whether it is easy to move the company's COMI to achieve a restructuring should be considered on a case by case basis, and depends on a number of factors such as: the jurisdiction of the company before and after migration, the technique of migration, shareholders' structure, the financial state of the company, and of course the views of creditors on the proposed move.

\section{Anna Kaczor}

Masters in Law, Warsaw University, specialising in European law, doctoral candidate; Masters in finance and banking, Warsaw School of Economics 